\title{
Are caregivers knowledgeable and interested in post-ICU outcomes?
}

\author{
AS Debue ${ }^{1 *}$, N Kentish-Barnes ${ }^{2}$, G Christine ${ }^{3}$, A Gressent ${ }^{4}$, F Iride $^{5}$, C Bridey ${ }^{6}$, S Calvino-Gunther ${ }^{7}$, S Cosserant ${ }^{8}$, \\ S Renard ${ }^{9}$, C Brossard $^{10}$, E Pichot ${ }^{11}$, B Megarbane $^{12}, \mathrm{~K} \mathrm{Klouche}^{13}$, D Flattres-Duchaussoy $^{14}$, C Leroy $^{15}$, C Bigot $^{8}$, \\ B Floccard $^{16}$, JD Chiche ${ }^{17,18}$, Post-ICU Study Group
}

From ESICM LIVES 2015

Berlin, Germany. 3-7 October 2015

\section{Introduction}

Long-term outcome after intensive care is a matter of growing interest in the critical care community. As better knowledge of post-ICU outcomes might help improve admission policies, processes of care, or end-of-life decisions, this topic is increasingly covered in medical journals. Access to this information may still be limited for ICU caregivers who play a pivotal role in the delivery of intensive care as well as in decision-making that lead to limitation of care. Whether ICU caregivers have a fair knowledge of long-term outcomes of ICU patients is unknown.

\section{Objectives}

Assess what is the knowledge of ICU caregivers related to long-term ICU outcomes.

\section{Methods}

This study was performed in 19 ICUs in France (12 MICUs, 5 mixed ICUs \& 2 SICUs). We designed and conducted a 42-item survey composed of 3 parts: i) demographic data to assess the profile of the caregivers, ii) caregiver's knowledge of outcome data and possible long-term outcomes for ICU patients, iii) caregivers's knowledge of discharge procedures in their ICU. The survey was distributed to all nurses, aid-nurses, chief-nurses and physiotherapists with a goal to collect at least 25 replies/centre. A specific questionnaire was filled by a senior investigator in each centre to collect centre characteristics and outcome data.

'Hôpital Cochin, Paris, France

Full list of author information is available at the end of the article

\section{Results}

The survey was completed by 445 caregivers (32 [IQ 2739] y.o.; $80 \%$ female) working in 19 ICUs as nurses (65.2\%), aid-nurses (23.6\%), chief-nurses (4\%), physiotherapists $(3.8 \%)$ or psychologists $(0.4 \%)$. Whereas $89 \%$ declare that they are interested in post-ICU outcomes, $84 \%$ claim they rarely obtain information about patients outcome after ICU discharge and 74\% wish they could « systematically obtain news from discharged patients ». Most caregivers claim that they mainly seek feedback from patients with prolonged ICU stays (74\%), patients with whom they had a privileged relationship (66\%), who had a striking personal history $(59 \%)$, or from young patients $(51 \%)$. Patients and their families are the main source of information regarding post-ICU outcomes through letters $(71 \%)$ or occasional visits (72\%). Still, $83 \%$ admit to have only rare occasions to meet with former patients. When meeting with former patients, the 2 main topics discussed with caregivers are ICU memories (74\%) and QOL (72\%), whereas less than $40 \%$ discuss physiological and psychological sequels.

\section{Conclusions}

Despite high-interest in understanding long-term outcomes of their patients, caregivers have a limited knowledge of what happens after ICU discharge and most ICUs have no systematic approach to collect long-term ICU outcomes. Creation of multidisciplinary post-ICU clinics could help caregivers to better understand the burden of post ICU sequels. 
Clermont Ferrand, Clermont Ferrand, France. ${ }^{9} \mathrm{CHU}$ Caen, Caen, France. ${ }^{10} \mathrm{CHU}$ Orléans, Orléans, France. ${ }^{11}$ Saint Joseph, Paris, France. ${ }^{12}$ Lariboisière, Paris, France. ${ }^{13} \mathrm{CHU}$ Montpellier, Montpellier, France. ${ }^{14} \mathrm{CHU}$ Nantes, Nantes, France. ${ }^{15} \mathrm{CHU}$ Angers, Angers, France. ${ }^{16} \mathrm{CHU}$ Lyon, Lyon, France. ${ }^{17} \mathrm{Hopital}$ Cochin, Assitance Publique Hôpitaux de Paris, Paris, France. ${ }^{18}$ Paris Descartes University, Paris, France.

Published: 1 October 2015

\section{Reference}

1. Griffiths RD, Jones C: In Intensive Care Aftercare. Oxford;ButterworthHeinemann 2002:

doi:10.1186/2197-425X-3-S1-A648

Cite this article as: Debue et al:: Are caregivers knowledgeable and interested in post-ICU outcomes? Intensive Care Medicine Experimental 2015 3(Suppl 1):A648.

\section{Submit your manuscript to a SpringerOpen ${ }^{\circ}$ journal and benefit from:}

- Convenient online submission

- Rigorous peer review

- Immediate publication on acceptance

- Open access: articles freely available online

- High visibility within the field

- Retaining the copyright to your article

Submit your next manuscript at $\gg$ springeropen.com 